Article

\title{
The Golden Activity of Lysinibacillus sphaericus: New Insights on Gold Accumulation and Possible Nanoparticles Biosynthesis
}

\author{
María Camila Bustos ${ }^{1}$, Humberto Ibarra ${ }^{2}$ and Jenny Dussán ${ }^{1, *(1)}$ \\ 1 Microbiological Research Center (CIMIC), Department of Biological Sciences, Universidad de los Andes, \\ Bogotá 111711, Colombia; mc.bustos198@uniandes.edu.co \\ 2 Microscopy Center, Universidad de los Andes, Bogotá 111711, Colombia; hibarraavila@uniandes.edu.co \\ * Correspondence: jdussan@uniandes.edu.co; Tel.: +57-1-339-4949
}

Received: 4 July 2018; Accepted: 23 July 2018; Published: 2 September 2018

\begin{abstract}
Power struggles surrounding the increasing economic development of gold mining give rise to severe environmental and social problems. Two new strains of Lysinibacillus sphaericus were isolated from an area of active alluvial gold mining exploitation at El Bagre, Antioquia. The absorption capacity of these strains and some of the L. sphaericus Microbiological Research Center (CIMIC) collection (CBAM5, OT4b.31, III(3)7) were evaluated by spectrophotometry according to a calibration gold curve of $\mathrm{HAuCl}_{4}{ }^{-}$with concentrations between $0 \mu \mathrm{g} / \mathrm{mL}$ and $100 \mu \mathrm{g} / \mathrm{mL}$. Bioassays with living biomass were carried out with an initial gold concentration of $60 \mu \mathrm{g} / \mathrm{mL}$. Their sorption capacity was evident, reaching percentages of gold removal between $25 \%$ and $85 \%$ in the first $2 \mathrm{~h}$ and $75 \%$ to $95 \%$ after $48 \mathrm{~h}$. Biosynthesis of possible gold nanoparticles (AuNPs) in assays with living biomass was also observed. Metal sorption was evaluated using scanning electron microscopy and energy-dispersive X-ray spectroscopy (EDS) analysis. The sorption and fabrication capacity exhibited by the evaluated strains of L. sphaericus converts this microorganism into a potential alternative for biomining processes, especially those related to gold extraction.
\end{abstract}

Keywords: mining; gold; Lysinibacillus sphaericus; sorption; nanoparticles; SEM

\section{Introduction}

Mining is an important worldwide activity; indeed, it influences and involves economic, political, environmental, and social aspects in a complex matrix. The exploitation of metallic and non-metallic minerals can be carried out in soil, sub-soil, or even in riverbeds. Nowadays, gold mining is a controversial topic; it is associated with negative impacts such as the adverse effects in terms of environmental pollution and high health risk due to excessive exposure to mercury and cyanide, especially in developing countries where illegal and artisanal mining are present [1].

In Colombia, the gold industry plays an important role in the economic development of the country. Colombia is the fourth producer of gold in South America, and is among the 20 major producers in the global ranking, besides developed countries and world powers as China, the United States, Russia, and Australia [2]. Because gold is the only financial asset which is not controlled, it is a meaningful commodity not only for Colombia but worldwide. Unfortunately, this is also the reason why the gold mining industry is associated with violence, power struggles in the country, and an excessive presence of illegal mining [3]. In Colombia, the highest percentage of environmental licenses and, consequently, exploited hectares are in the departments of Choco and Antioquia [2]. The direct repercussions in these areas are the adverse environmental effect on water bodies, destruction of the diversity, and important health problems emerging in the surrounding communities $[4,5]$. 
It is true that areas with active mine exploitation represent challenging environments for microorganisms, due to their extreme conditions such as high pressure and temperature, elevated salt concentrations, a diverse range of acid and alkaline soil/water, and many others abiotic factors [6]. However, an impressive diversity of microorganisms has been found in these types of habitats including those associated with gold mining activity, where communities of Phylum Proteobacteria, Firmicutes and Actinobacteria, are predominant [7-10]. Despite the fact that the most abundant organisms are bacteria, representatives of the Archea and Eukarya domains have also been found [11-13]. The ample metabolic capacity of the organisms present in these areas is evident, and their ability to act as $\mathrm{Fe}, \mathrm{S}, \mathrm{NH}_{3}$, and $\mathrm{CH}_{4}$ oxidants and $\mathrm{SO}_{4}{ }^{2-}$ reducers has been proven [8,14-17].

Microorganisms present great potential in sustainable mining, due to their metabolic capacities. For example, it has been demonstrated that some of them accelerate the process of sulfur oxidation and, as such, can be used in biomining and bioleaching [18]. Additionally, acidophilic microorganisms have allowed the development of different strategies for the remediation of important contamination problems in the exploitation of minerals; for example, the regulation and management of $\mathrm{pH}$ in the precipitation of iron in acid mine drainage (AMD) [19]. Furthermore, microorganisms, especially bacteria, have great potential in terms of the immobilization and accumulation of heavy metals such as $\mathrm{Cu}, \mathrm{Pb}, \mathrm{Cr}$, and $\mathrm{Fe}$, among others [20-24]. In this sense, they have the capacity to be used as an ideal alternative for remediation of contaminated sites, and an alternative to recover precious metals.

Gold exploitation is becoming increasingly important due to growing demand for the metal. This puts pressure on the industry to incorporate new methodologies and processes for efficient, less expensive, and ecologically sustainable extraction. In the biochemical cycle of the metal, secondary gold can be formed as a result of oxidation, solubilization, reduction, and precipitation of the ore under surface conditions due to microorganism activity [25]. Wide spectrums of organisms such as fungi, algae, and, in particular, bacteria have proved their potential for gold biomining at different stages of metal extraction and purification [26-29].

Lysinibacillus sphaericus, a sporulated gram-positive bacillus has become a focus of sustainable economic industry development because of its capacity for metal binding and remediation of contaminated matrices [30,31]. The first strain that exhibited metal binding capabilities was the JG-A12 (isolated from a uranium mining waste pile in Germany), which accumulated $\mathrm{U}, \mathrm{Cu}, \mathrm{Pb}, \mathrm{Al}$ and $\mathrm{Cd}$ on its surface [32]. Others strains of the genus also manifest these sorption abilities with diverse metals such as $\mathrm{Fe}, \mathrm{Cr}, \mathrm{Zn}$, among others [21,22,33].

The aim of the present study was to elucidate the ability of gold absorption by two new strains of L. sphaericus isolated from an area of active alluvial gold mining exploitation at El Bagre, Antioquia. The bioassays carried out showed efficiency in bioaccumulation and biosorption of gold in living cells, as well as the possible fabrication of nanoparticles.

\section{Materials and Methods}

\subsection{Study Samples}

Sampling was carried out in the exploitation territory of the company Mineros S.A., which specializes in alluvial gold mining in the Nechi River in the department of Antioquia, Colombia. This area is about 43,000 hectares with the following coordinates: $7^{\circ} 39^{\prime} 73 \mathrm{~N}, 74^{\circ} 47^{\prime} 22.73 \mathrm{O}$. Water samples were collected from different points throughout the gold exploitation process: Near to suction dredge, scoop dredge, moisture, and site of restoration at the initial phase. These samples were subjected to thermal shock to detect sporulated gram-positive bacilli. Five $\mathrm{mL}$ per sample was taken to be subjected to a temperature of $90^{\circ} \mathrm{C}$ for $20 \mathrm{~min}$. Dilutions from $10^{-1}$ and $10^{-2}$ were used. All cultures were carried out in duplicate and incubated for $48 \mathrm{~h}$ at $30^{\circ} \mathrm{C}$ in nutrient agar (NA) [34]. 


\subsection{L. sphaericus Strain Identification}

For morphotypes identification, 16S rDNA gene amplification, sequencing, and phylogenetic analysis were carried out. Primers 27F (AGAGTTTGATCMTGGCTCAG) and 1493R (TACGGYTACCT TGTTACGACTT) [35] were used to amplify the $16 \mathrm{~S}$ rDNA gene. For amplifications, $25-\mu \mathrm{L}$ reactions were prepared containing $100 \mu \mathrm{M}$ each dNTPs, $0.2 \mu \mathrm{M}$ of each primer, $3 \mathrm{mM} \mathrm{MgCl} 2,2 \mathrm{U}$ Taq polymerase (Bioline), 1X PCR buffer, and $1 \mu \mathrm{L}$ of crude extract from an overnight culture as the template DNA source. The amplification program consisted of a denaturing step of $94{ }^{\circ} \mathrm{C}$ for $3 \mathrm{~min}, 25$ cycles of denaturing for $45 \mathrm{~s}$ at $94{ }^{\circ} \mathrm{C}$, annealing for $45 \mathrm{~s}$ at $50{ }^{\circ} \mathrm{C}$, and extension at $72{ }^{\circ} \mathrm{C}$ for $45 \mathrm{~s}$ and a final extension of $72{ }^{\circ} \mathrm{C}$ for $7 \mathrm{~min}$. The PCR products were visualized in $1.0 \%$ agarose gels, then purified and sequenced by Macrogen Inc. (Seoul, Korea). Resulting sequences were compared with NCBI and RDP databases. The phylogenetic tree was constructed using sequences of L. sphaericus and Bacillus sp. reference strains obtained from GenBank. The phylogenetic tree choosen was the one that exhibited the minor Bayesian Information Criterion (BIC).

Additionally, characterization by the presence of S-layer protein and MTX and Bin toxins, and toxicology bioassays in larvae of Culex quinquefasciatus and Aedes aegypti were also performed [36]. The nucleotide sequences of the L. sphaericus strains from this study were deposited in the GenBank database under the accession numbers MH447519 and MH447518. A summary of the strains used in this study are shown in Table 1.

Table 1. Strains evaluated in the bioassays of this study.

\begin{tabular}{ccc}
\hline Lysinibacillus sphaericus Strains & Site of Isolation & Reference \\
\hline MCB1 & Nechi River & This study \\
MCB2 & Nechi River & This study \\
CBAM5 & Hydrocarbon-contaminated soil & {$[30]$} \\
III(3)7 & Oak forest soil & {$[30]$} \\
OT4b.31 & Coleopteran larvae & {$[30]$} \\
\hline
\end{tabular}

\subsection{Calibration Curve for Gold Determination $\left(\mathrm{HAuCl}_{4}\right)$}

For the calibration curve, $0.01 \mathrm{~g}$ of pure gold was dissolved in $20 \mathrm{~mL}$ of aqua regia and evaporated until the solution was near to dryness. Then, it was dissolved in approximately $2 \mathrm{~mL}$ of concentrated $\mathrm{HCl}$ and diluted with deionized water to $100 \mathrm{~mL}$ in a measuring flask [37]. Series of $20 \mathrm{~mL}$ for gold standard solutions between 0 and $100 \mu \mathrm{g} / \mathrm{mL}$ were used for the calibration curve. The absorption spectrum used was $313 \mathrm{~nm}$ and the linear regression equation obtained was $\mathrm{A}=0.0251 \mathrm{C}-0.0101$; $\mathrm{R}^{2}=0.9996$.

\subsection{Metal Sorption in L. sphaericus Strains}

Sorption was evaluated by spectrophotometry of the biomass suspended in minimal salt medium (MSM) with sodium acetate at $0.5 \%$ [21]. Experiments were carried out in triplicate and with a $\mathrm{HAuCl}_{4}{ }^{-}$ concentration of $60 \mu \mathrm{g} / \mathrm{mL}$. The total volume was $15 \mathrm{~mL}$ in $50 \mathrm{~mL}$ flasks with a concentration between $10^{6}$ and $10^{7} \mathrm{UFC} / \mathrm{mL}$. Gold within the cells was determined through supernatant measurements taken every $15 \mathrm{~min}$ for $2 \mathrm{~h} \mathrm{[21]} \mathrm{and} \mathrm{a} \mathrm{final} \mathrm{determination} \mathrm{was} \mathrm{made} \mathrm{at} 48 \mathrm{~h}$ for the possible formation of AuNPs.

The bioassays were carried out using CBAM5, OT4b.31 and III(3)7 strains, from the L. sphaericus CIMIC collection $[30,38,39]$. For these strains, the determinations were carried out using the mixture of the three strains and CBAM5 alone. The latter (CBAM5) was used for methods calibration due to its capacity to capture mercury [38]. This metal is highly likely to be found in the Nechi River, due to the presence of illegal and artisanal gold mining. Additionally, bioassays using the isolated strains of this study were also performed: L. sphaericus MCB1 and MCB2 as individual strains and as a mixture. 
The light, oxygen, temperature, and agitation conditions were controlled, keeping the experiments in darkness with $150 \mathrm{rpm}$ and a constant temperature of $30^{\circ} \mathrm{C}$ [26].

\subsection{SEM and EDS Analysis}

The samples were fixed in $2.5 \%$ glutaraldehyde for $7 \mathrm{~h}$ followed by a process of dehydration through rinsing in an increasing ethanol gradient [40]. Modifications of previous protocol were carried out for the final steps. For sample mounting, briefly, a drop of approximately $5 \mathrm{uL}$ of each sample was placed on an aluminum support and dried at room temperature for its posterior SEM observation and metal semi quantitation with energy-dispersive $\mathrm{X}$-ray spectroscopy (EDS) using a JEOL JSM-6490LV (JEOL, Tokyo, Japan) scanning electron microscope equipped with an Oxford INCA PentaFetX3 EDS detector.

Samples were prepared for metal determination inside the cell, using a modification of previous protocols [41]. After glutaraldehyde fixation, a gradient between ethanol and resin was carried out until the sample was $100 \%$ embedded in just resin. Then, the sample was heated for $24 \mathrm{~h}$ at $56{ }^{\circ} \mathrm{C}$. After polymerization, samples were cut using Leica ULTRACUT UC7 microtome to obtain $70 \mathrm{~nm}$ thick slices, which were placed on 200 mesh cupper grids. Uranyl acetate was used as contrast agent. Samples were observed using a Tescan LYRA 3 Scanning electron microscope (TESCAN, Brno, Czech Republic).

\section{Results}

\subsection{Sporulated Microorganisms}

A total of 12 morphotypes were identified as sporulated microorganisms. Although the majority of them were gram variable or positive bacilli, gram-negative cocci and bacilli were also found in the samples. Only two morphotypes were identified as L. sphaericus through PCR of complete $16 \mathrm{~S}$ and a posterior sequencing and analysis in NCBI and RDP databases. The phylogenetic tree was inferred by using the Maximum Likelihood method based on the Kimura 2-parameter model [42]. The tree with the highest log likelihood is shown (Figure 1). The percentage of replicate trees, in which the associated taxa clustered together in the bootstrap test (1000 replicates), are shown next to the branches. Initial tree(s) for the heuristic search were obtained automatically by applying Neighbor-Join and BioNJ algorithms to a matrix of pairwise distances estimated using the Maximum Composite Likelihood (MCL) approach, and then the topology with superior log likelihood value was selected. A discrete Gamma distribution was used to model evolutionary rate differences among sites $(5$ categories $(+G$, parameter $=0.0500)$ ). Evolutionary analyses were conducted in MEGA X [43].

Additionally, tests were also carried out as confirmation probes. In both cases, the shape of the spore was terminal, the toxic bioassays show mortality for the larvae of C. quinquefasciatus and A. aegypti and the presence of the S-layer protein was evident (Figure S1, Table S1). This protein is intrinsically associated with metal accumulation due to its characteristic morphology. It is the outermost layer of the microorganisms, composed of a single protein or a group of glycoprotein monomers and with a capability for self-assembly $[44,45]$. By virtue of this, microorganisms with S-layer are a potential tool for processes of bioremediation and biotechnology. Following these tests, the morphotypes were identified as L. sphaericus. Because they are new strains, their denotation in this study from now on will be MCB1 and MCB2 with the accession numbers MH447519 and MH447518, respectively, in the NCBI. 


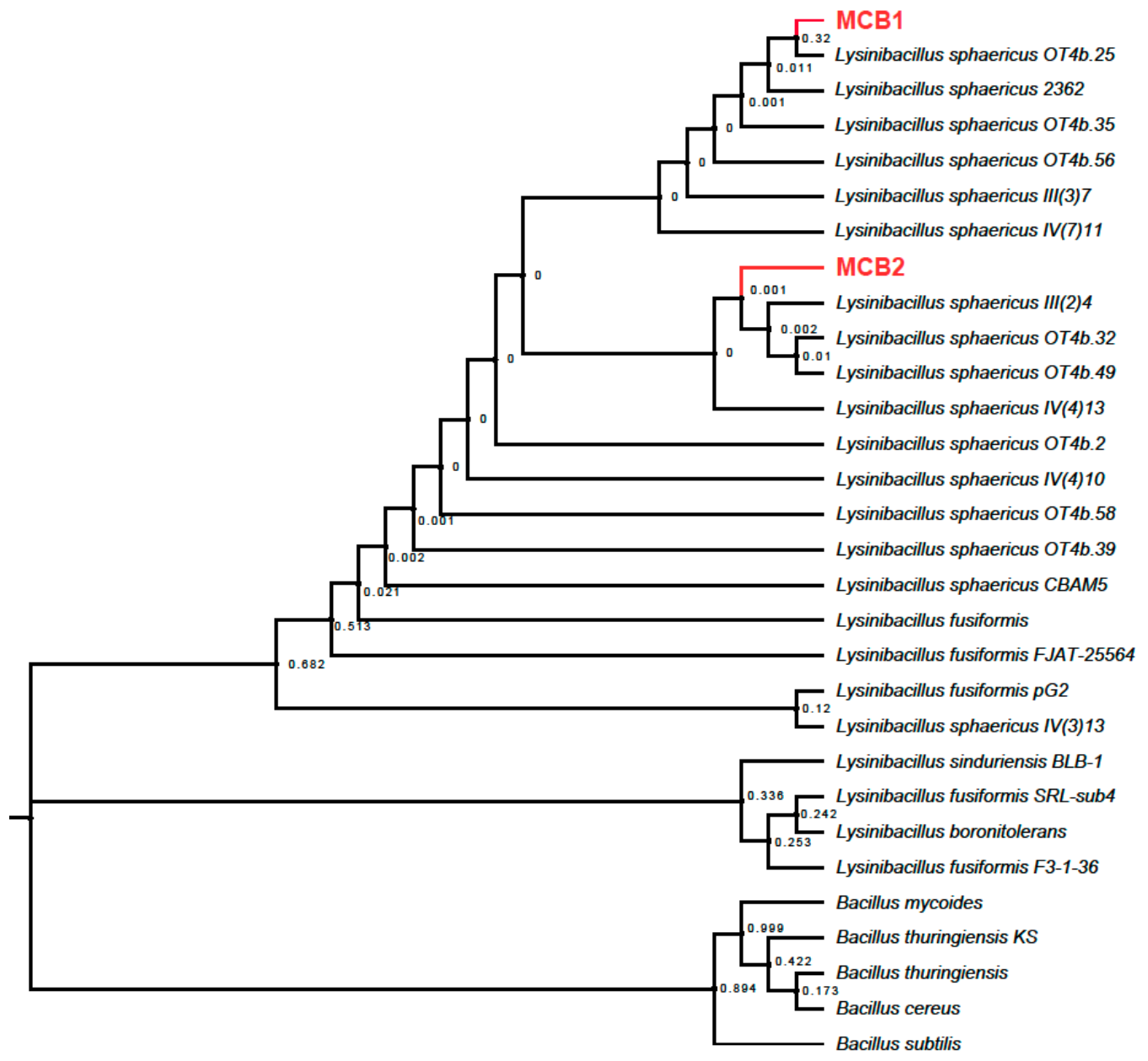

Figure 1. Phylogenetic tree for Lysinibacillus sphaericus with the two new strains isolated, MCB1 and MCB2.

\subsection{Metal Sorption in Living Cells of L. sphaericus Strains}

The individual strain CBAM5, used as a calibration method, reached a percentage of recovery of $60 \%$ in the first $3 \mathrm{~h}$ of the bioassay and approximately $95 \%$ after $48 \mathrm{~h}$ (Figure $2 \mathrm{a}$ ). The mixture of strains CBAM5, OT4B.31, and III(3)7 from the L. sphaericus CIMIC collection was the bioassay with the highest percentage of metal recovery, followed by CBAM5 alone (Figure 2a,b). Furthermore, CBAM5 had a similar percentage of metal recovery when is compared to the mixture between the new isolations of L. sphaericus MCB1 and MCB2, but this was reached in a shorter time, $30 \mathrm{~min}$ (Figure 2b,c). On the other hand, the highest percentage of metal recovery was $24.27 \%$ for MCB1 and almost the double for MCB2 at 41.45\% (Figure 2c,d). A mixture of MCB1 and MCB2 also demonstrated the microorganism's capability to capture this metal (Figure 2e). It is important to mention that the highest percentage of metal recovery $(60.76 \%)$ was achieved in a shorter time when the strains were mixed than when they were used on their own (Figure 2c-e). Controls in all cases were above the absorbance for the treatments with L. sphaericus presence.

For all the bioassays performed, a similar pattern was detected. In the initial phase, a quick increment in the percentage of gold recovery was represented in a drastic fall of the absorbance. Subsequently, there were a series of oscillations until the end of the experiment (Figure 2).

As mentioned earlier, the presence of oscillations in the last stages of the experiments can suggest the presence of efflux pumps. Behavior models of these pumps were similar to the previously described reports for the same species but for the heavy metals, chrome and lead [21,39]. 


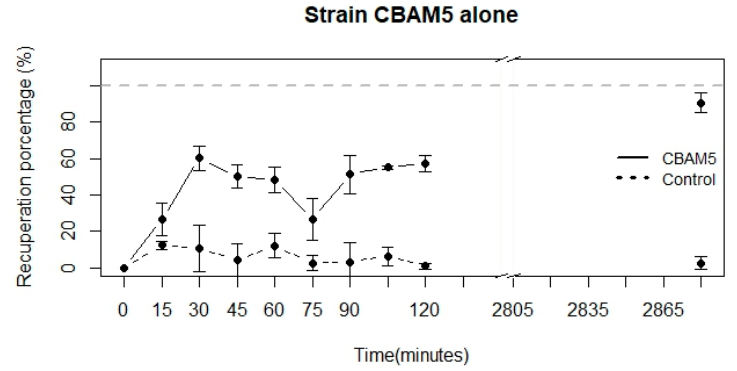

(a)

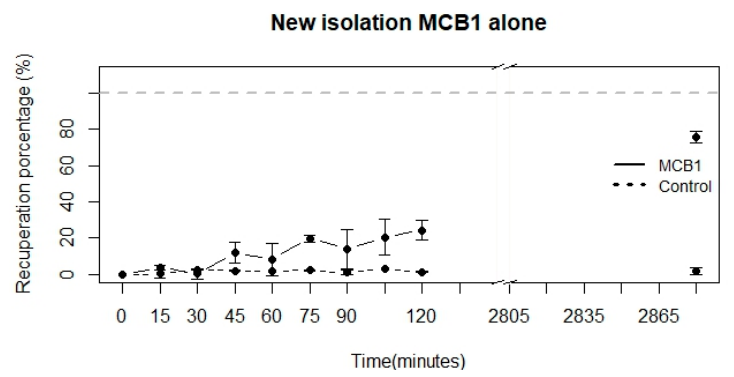

(c)

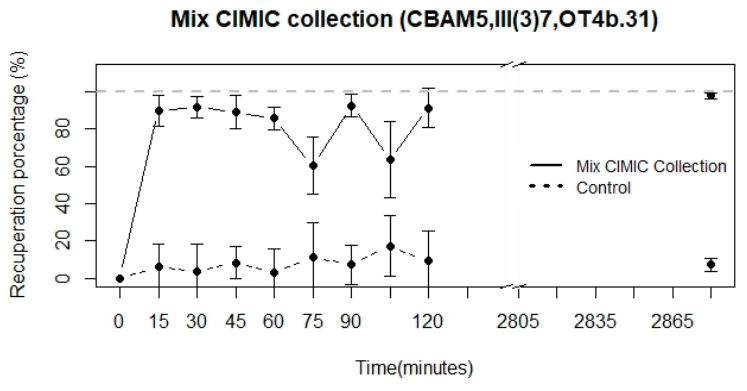

(b)

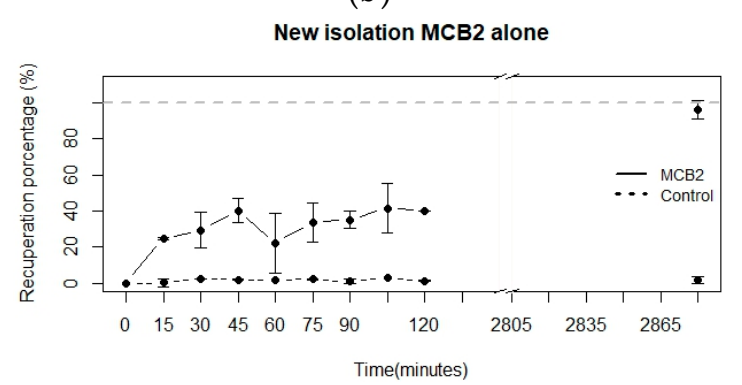

(d)

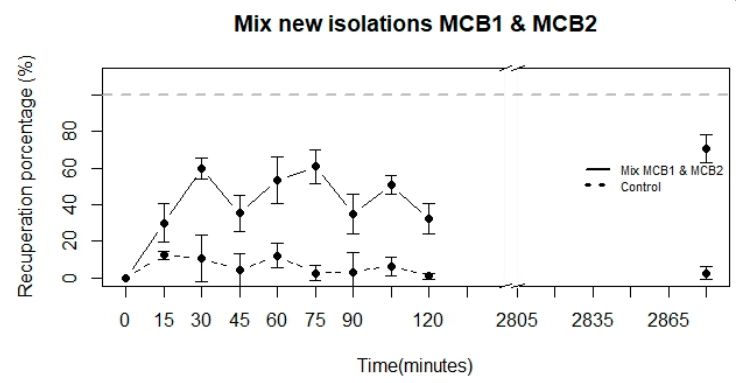

(e)

Figure 2. Bioassay in living cells with the L. sphaericus (a) CBAM5 as an individual strain, (b) CIMIC collection (CBAM5, OT4b.31, III(3)7) in a mix, (c) MCB1 and (d) MCB2 alone, and (e) mix with MCB1 and MCB2. The concentration of $\mathrm{HAuCl}_{4}{ }^{-}$evaluated was $60 \mu \mathrm{g} / \mathrm{mL}$ in minimum salt medium. Graphs show deviation standard for each time evaluated.

\subsection{Biofabrication of Gold Nanoparticles (AuNPs)}

Possible biosynthesis of AuNPs in the strains evaluated was observed. After $48 \mathrm{~h}$, the treatment flasks with the bacteria turned to a strong red-purple color (Figure 3). In the biological formation of AuNPs this color is very characteristic and in the majority of cases, it is a process that takes place several hours after the contact between the microorganism and the metal $[28,29,46,47]$.

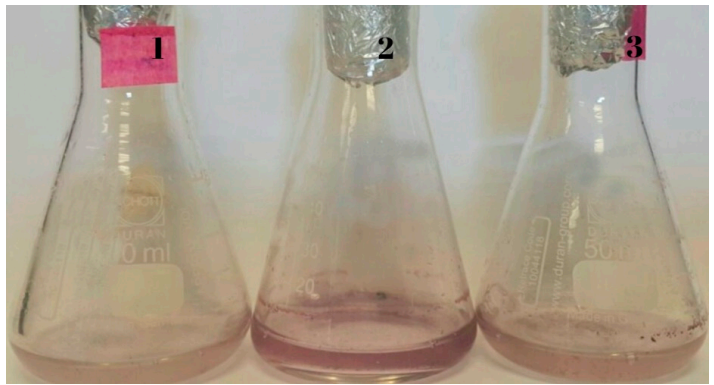

(a)

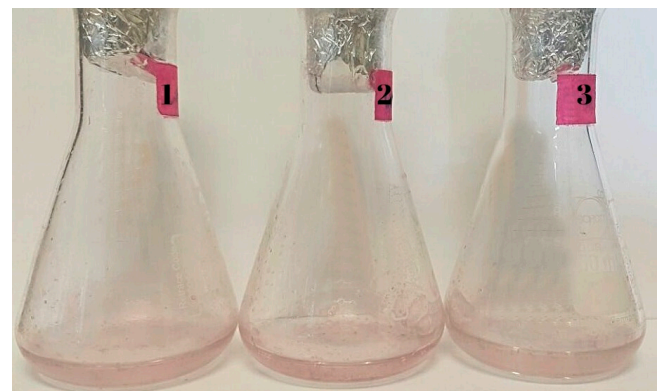

(b)

Figure 3. Cont. 


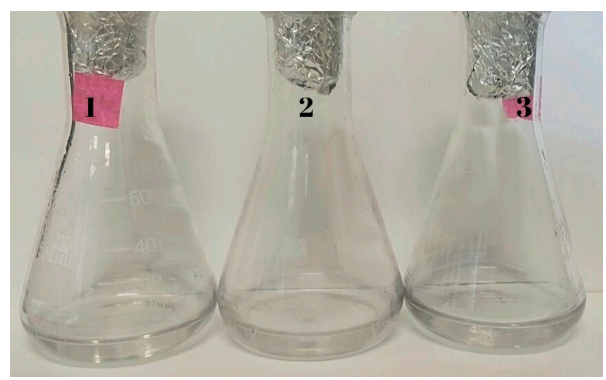

(c)

Figure 3. Bioassays of possible formation of gold nanoparticles with living cells for the strains (a) CBAM5 alone, (b) mix of MCB1 and MCB2 and, (c) control after $48 \mathrm{~h}$. The numbers in the flasks are the replicates for each bioassay.

For living cells, gold colloids did not have a specific formation around the cell or a clear pattern of accumulation; they were all over the surface (Figure 4). Additionally, some of the particles were not attached to the cells, but free in the area. These possible AuNPs varied in size from $50 \mathrm{~nm}$ to $100 \mathrm{~nm}$. In general, the shape of all L. sphaericus strains were elongated and thin, possibly due to the pressure they were subjected to, with an acid pH solution and high gold concentrations. L. sphaericus CBAM5 shows clusters of possible, small AuNPs (Figure 4a,b). The possible AuNPs observed in the mixture between the strains from the CIMIC collection were not clumped, but rather dispersed throughout the surface covered by the cells (Figure 4c,d). MCB1 and MCB2 show bigger clumps of gold compared with the strains from the CIMIC collection (Figure $4 \mathrm{e}-\mathrm{h}$ ). Finally, the mixture of these strains also reveals dispersion all over the cell surface as in the mixture of the CBAM, OT4b.31, and III(3)7 strains (Figure $4 \mathrm{i}, \mathrm{j})$.

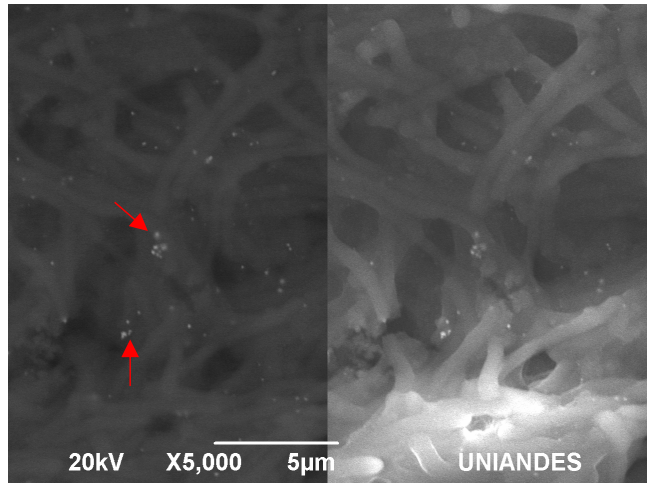

(a)

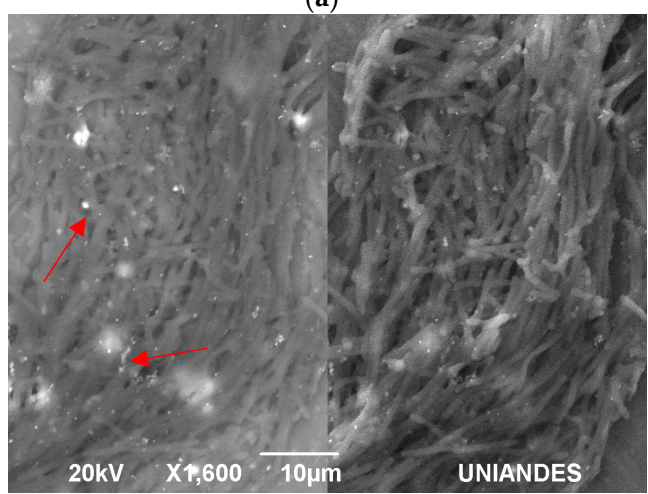

(c)

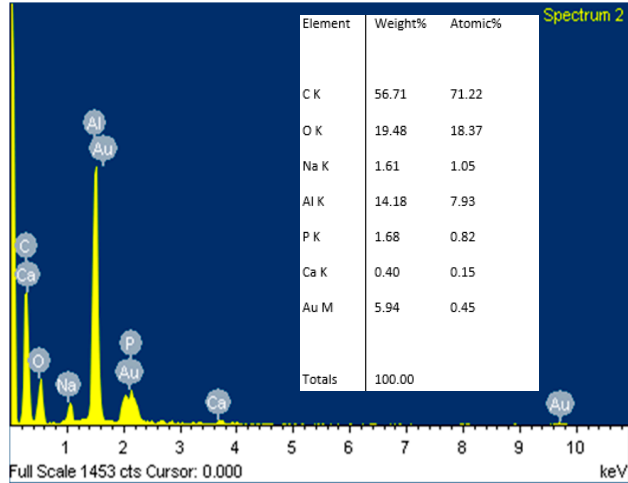

(b)

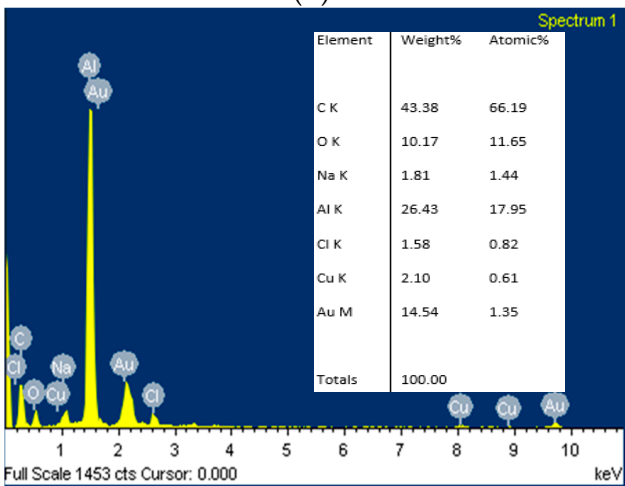

(d)

Figure 4. Cont. 


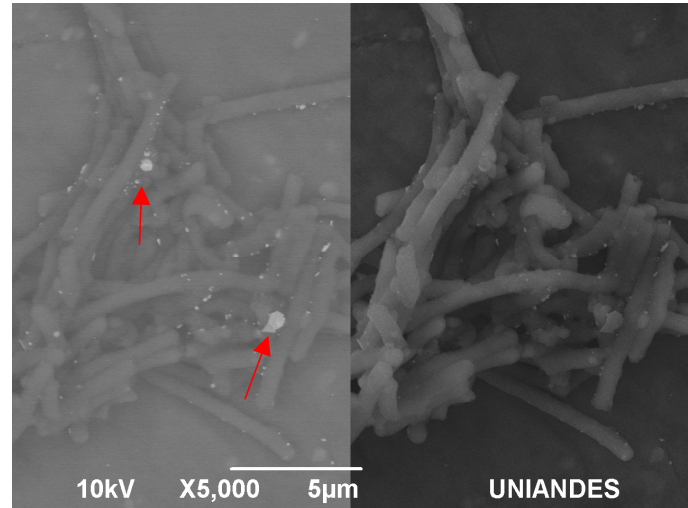

(e)

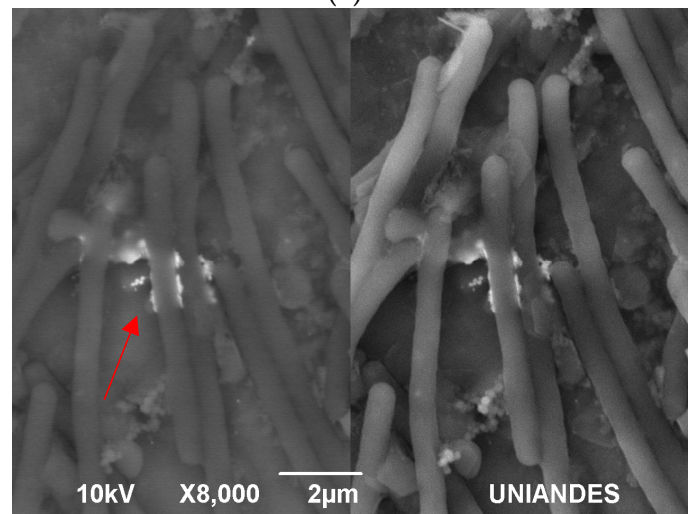

(g)

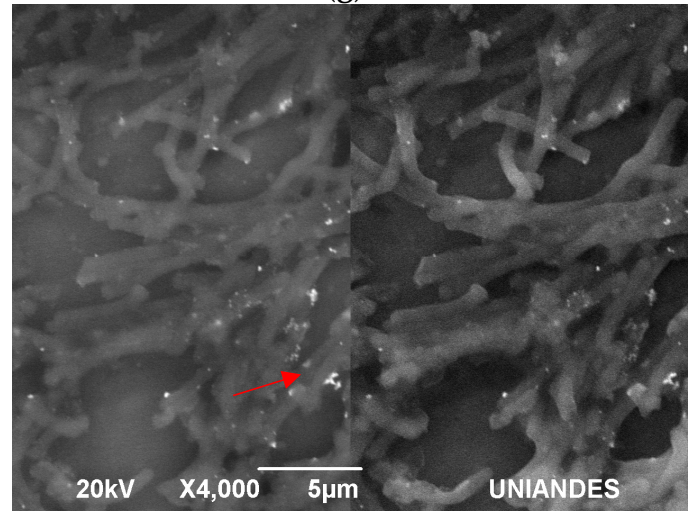

(i)

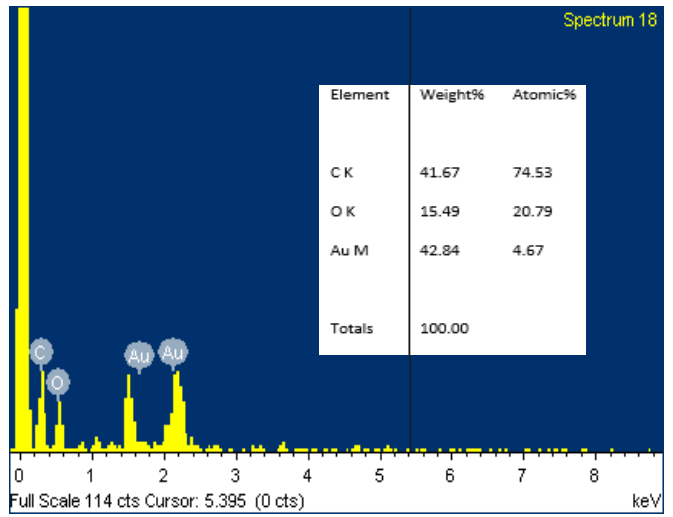

(f)

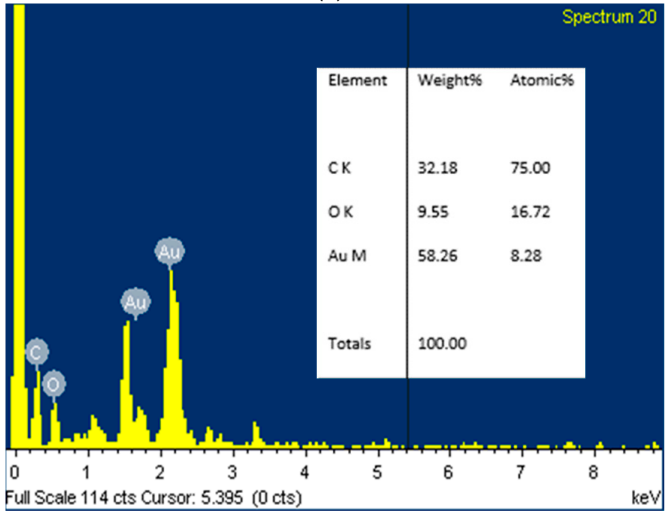

(h)

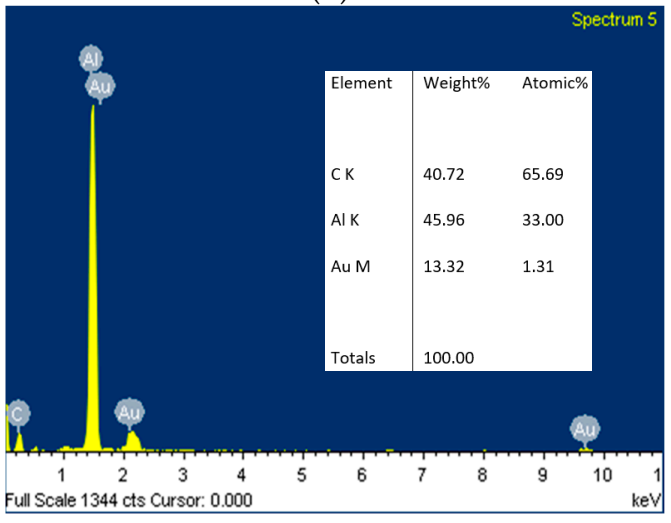

(j)

Figure 4. SEM images with SEI (secondary electrons) and BEC (Backscattered electrons) for bioassays with living cells of Lysinibacillus sphaericus (a) CBAM5 and (b) energy-dispersive X-ray spectroscopy (EDS) analysis; (c) mix of CIMIC collection strains (CBAM5, OT4b.31, III(3)7) with (d) EDS analysis. Additionally, L. sphaericus (e) strain MCB1 alone with its respective (f) EDS analysis and (g) MCB2 also with (h) EDS analysis. Similarly, the (i) mix between MCB1 and MCB2 and (j) EDS analysis.

On the other hand, it was evident for the samples immersed in resin, that the gold was also inside the cell (Figure 5). The L. sphaericus strains MCB1 and MCB2 evaluated were able to adsorb and absorb gold, showing possible AuNPs inside and outside of the membrane. It was also remarkable that gold was also accumulated even when the cells were in the sporulation process (Figure 5a,b) or in vegetative stages (Figure 5c). The previous statement, suggests that the cycle stage of the microorganism is not an important factor that influences the biosynthesis or accumulation of the metal. 

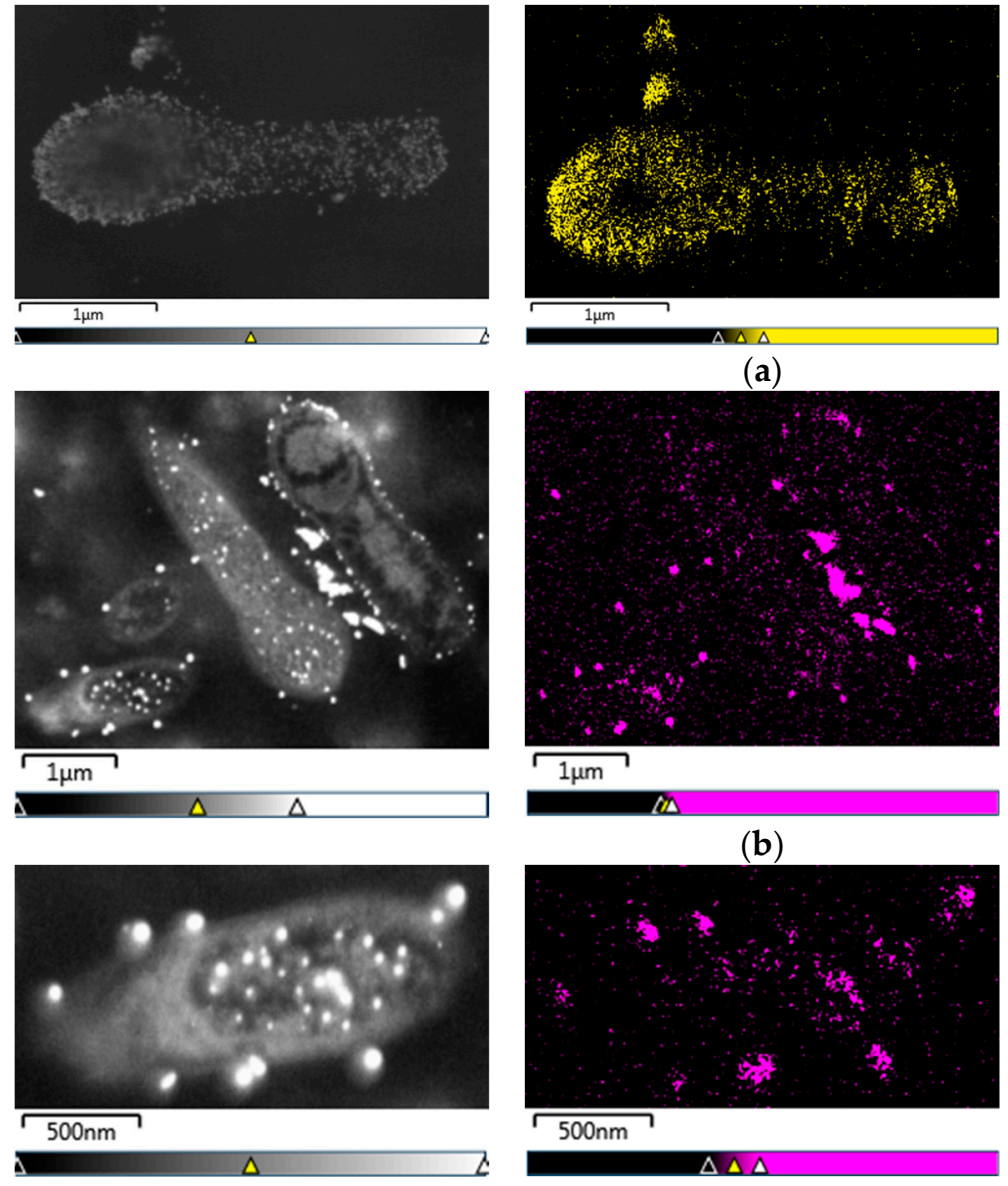

(a)

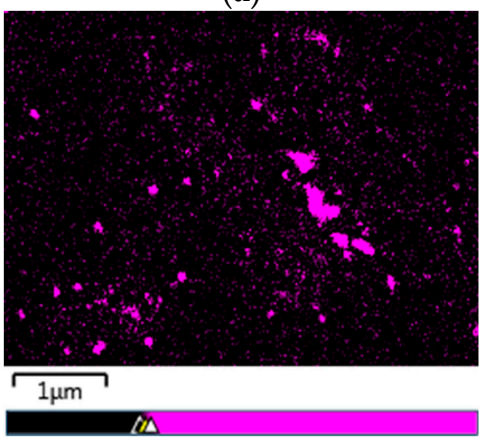

(b)
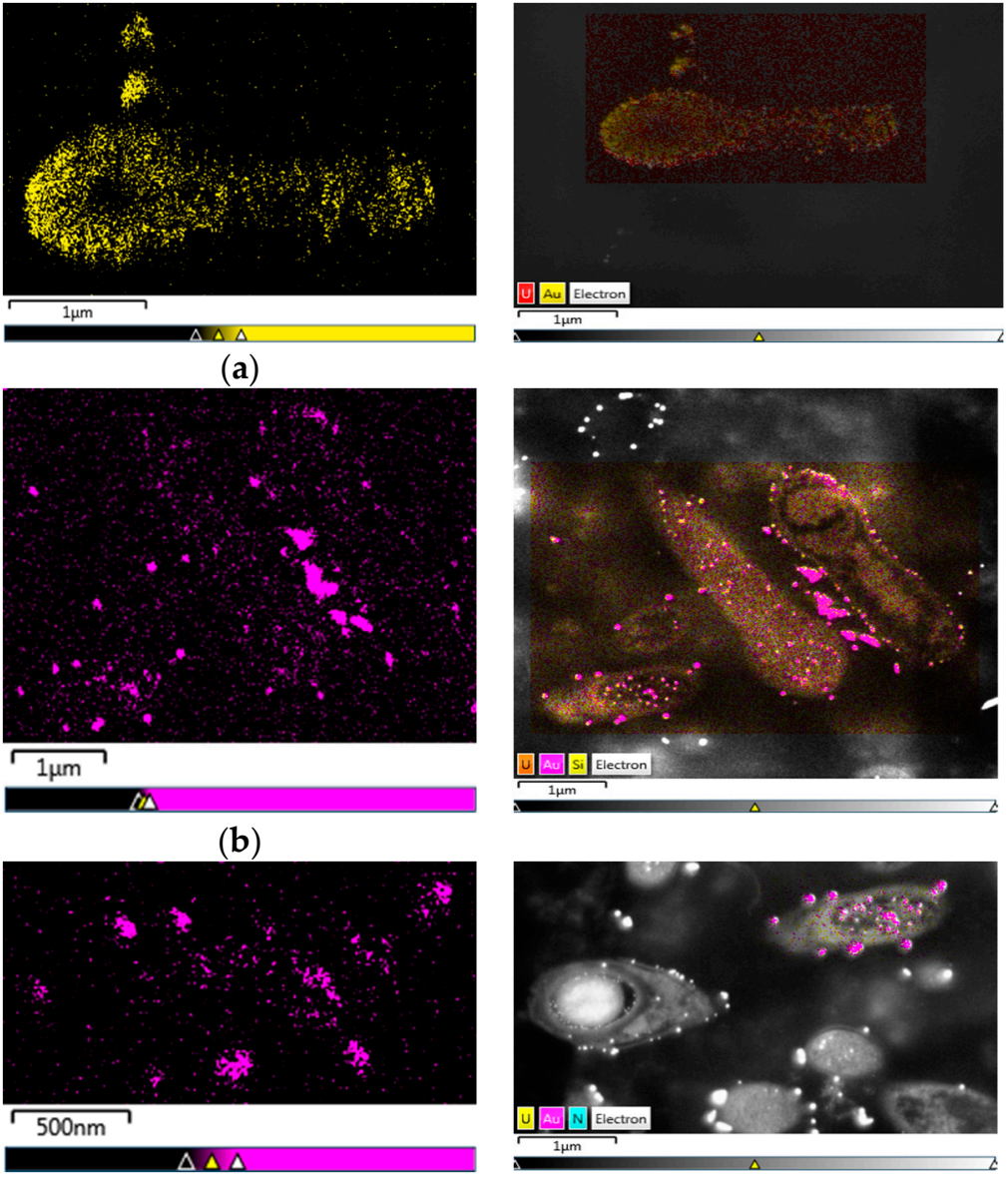

(c)

Figure 5. SEM and EDS analysis maps for samples of the mix between Lysinibacillus sphaericus MCB1 and MCB2 prepared in resin. Slides of $70 \mathrm{~nm}$ show cells $(\mathbf{a}, \mathbf{b})$ in different sporulation stages and in (c) a vegetative cell.

\section{Discussion}

The capability to bioabsorb gold of the two new strains of L. sphaericus MCB1 and MCB2 is indisputable, as well as of the strains of CIMIC collection. These abilities present great potential in the gold mining industry, particularly in the extraction process. Biological methodologies are generally low-cost techniques with high efficiencies, which make them attractive and adaptable to developing countries such as Colombia, where illegal and artisanal mining are present. These types of gold mining are characterized by the excessive use of mercury and cyanide, and the release of these heavy metals into the environment without any kind of pollution or health control [2,3]. The high efficiency shown by the strains, especially when in a mixture, makes L. sphaericus a promising candidate for gold biomining.

Bioassays using the mixtures had higher efficiencies than the ones with only one strain, displaying the benefits of mutualistic behavior by the microorganisms. It is also important to highlight the almost $100 \%$ recovery of gold by L. sphaericus MCB2, a native strain of the Nechi river at El Bagre, Colombia. This recovery was obtained in less than $50 \mathrm{~h}$ and with possible formation of gold nanoparticles or colloids.

Oscillations in the last stages of bioassays with live biomass suggest the presence of efflux pumps, an indirect mechanism of the cell for the introduction of divalent ions such as lead and chrome [21,40]. Also, this mechanism is proposed given that this metal does not bring any biological benefit to the cell. This strategy is known for other microorganisms because it is an evasion mechanism against 
metal accumulation and, consequently, it can confer resistance [48,49]. Additionally, L. sphaericus has a layer that surrounds the entire cell, known as the S-layer protein. The presence of the protein can confer important advantages to the microorganisms. It is demonstrated that bacteria with this protein possess diverse mechanisms for metal interactions and biotransformation; this includes biosorption and accumulation, but also acts as a protective structure in environments that are harmful for the cells such as active mining zones [50,51].

The possible synthesis of gold nanoparticles has many benefits for medicine, agriculture, the cosmetic industry, drug delivery, and biochemical sensors [52,53]. For example, AuNPs synthesized by the fungi Candida albicans have been studied as a tool for the early detection of liver cancer [54]. The general mechanism for microbial synthesis of gold nanoparticles is the reduction of $\mathrm{Au}$ (III) ionic form to $\mathrm{Au}(0)$ or AuNPs [26]. The mechanism involves electrostatic interactions of the positive charge that the metal ions have, with the negative charge of the cell wall [52]. Many metabolic processes are proposed for the bio-mineralization of gold by the microbes such as the presence of organic phosphate compounds, ligninases, laccases, reductases (NADH/NADPH), amino acids (tyrosine, cysteine and tryptophan), the lack of specific metal transport systems, and extracellular complexation and efflux systems [51,52]. The production of AuNPs can be associated to detoxification in toxic environments, transforming metal ions to insoluble complexes. In this sense, the ability to form metal agglomerations can be used as an eco-friendly technique in the mining industry for different metals.

We propose that the mechanism by which L. sphaericus can synthesize gold is the presence of mer clusters. It is known that these genes confer $\mathrm{Hg}$ resistance, and are inducible in the presence of low concentrations of heavy metals in the environment. It suggests a cross-regulation of the $\mathrm{Hg}$ systems by $\mathrm{Au}(\mathrm{III})$ because of their physicochemical similarity [26]. The specific mechanism by which this occurs in L. sphaericus is still unknown and it will be the aim for future research.

To continue research in this field, it is important to evaluate the selectivity of the strains for the metal, due to the fact that the water effluent may contain other heavy metals such as mercury. Additionally, studies estimating the potential of the S-layer protein should also be performed, given its capacity of accumulate metal ions. Finally, the development of a bioreactor as a pilot could be an important approach to the real conditions that L. sphaericus is subject to in obtaining gold without mercury or cyanide.

\section{Conclusions}

The two new strains of L. sphaericus, as well as the ones from the CIMIC collection, show an elevated percentage of gold recovery, reaching $95 \%$ in less than $50 \mathrm{~h}$. This bacterium can be a potential tool in the extraction of gold in Colombia due to its diverse advantages including efficiency, fast processing, the low cost of the technique, an environmentally friendly approach, health safety, and the use of native strains. These strains also have the ability to bio-produce possible gold nanoparticles in short time intervals, making them a more attractive alternative.

Supplementary Materials: The following are available online at http:/ / www.mdpi.com/1996-1944/11/9/1587/ s1, Figure S1: Image of optic microscope 100 $\times$ and SEM of sporulation cycle of L. sphaericus MCB1 and MCB2. Figure S2: SDS-PAGE gel of S-layer purification in MCB1 and MCB2, Table S1: Mortality bioassays with L. sphaericus on larvae of $C$. quinquefasciatus and A. aegpti.

Author Contributions: Conceptualization, M.C.B. and J.D.; Formal analysis, M.C.B.; Investigation, M.C.B., J.D. and H.I.; Methodology, M.C.B., H.I. and J.D.; Project administration, J.D.; Supervision, J.D.; Writing—original draft, M.C.B.; Writing-review \& editing, M.C.B., H.I. and J.D.

Funding: This research was funded by the Research Fund at the School of Science at Universidad de los Andes and the Microbiological Research Center (CIMIC) and the APC was funded by School of Science at Universidad de los Andes and Vortex Company SAS.

Acknowledgments: We like to thank TESCAN for the support of the LYRA application laboratory at TOH in Brno, Czech Republic, and Vortex Company Colombia for facilitate the images of FIB-SEM taken in this study. Additionally, we also want to thank Paula Rojas for her kind reviewing of the manuscript and their invaluable suggestions, Tito Peña-Montenegro and Esteban Pardo for their useful help in the construction of the phylogenetic tree, and to Tiziana Laudato for the language assistance 
Conflicts of Interest: The authors declare no conflicts of interest.

\section{References}

1. Kumah, A. Sustainability and gold mining in the developing world. J. Clean. Prod. 2006, 14, $315-323$. [CrossRef]

2. Giraldo, J.; Muñoz, J.C. La minería en Antioquia: Entre la informalidad y la criminalidad. In Informalidad e Ilegaidad en la Explotación del ORO y la MADERA en Antioquia; Universidad Eafit, Fundación Proantiquia, Centro de Análisis Político: Medellín, Colombia, 2012; pp. 25-100, ISBN 978-958-99013-2-8.

3. Idrobo, N.; Mejía, D.; Tribin, A.M. Illegal gold mining and violence in Colombia. Peace Econ. Peace Sci. Publ. Policy 2014, 20, 83-111. [CrossRef]

4. Olivero-Verbel, J.; Carranza-Lopez, L.; Caballero-Gallardo, K.; Ripoll-Arboleda, A.; Muños-Sosa, D. Human exposure and risk assessment associated with mercury pollution in the Caqueta River, Colombian Amazon. Environ. Sci. Pollut. Res. Int. 2016, 23, 20761-20771. [CrossRef] [PubMed]

5. Tarras-Wahlberg, N.H.; Flachier, A.; Lane, S.N.; Sangfors, O. Environmental impacts and metal exposure of aquatic ecosystems in rivers contaminated by small scale gold mining: The Puyango River basin, southern Ecuador. Sci. Total Environ. 2001, 278, 239-261. [CrossRef]

6. Takai, K.; Moser, D.P.; DeFlaun, M.; Onstott, T.C.; Fredrickson, J.K. Archaeal Diversity in Waters from Deep South African Gold Mines. Appl. Environ. Microbiol. 2001, 67, 5750-5760. [CrossRef] [PubMed]

7. Inagaki, F.; Takai, K.; Hirayama, H.; Yamato, Y.; Nealson, K.H.; Horikoshi, K. Distribution and phylogenetic diversity of the subsurface microbial community in a Japanese epithermal gold mine. Extremophiles 2003, 7, 301-317. [CrossRef] [PubMed]

8. Rastogi, G.; Osman, S.; Kukkadapu, R.; Engelhard, M.; Vaishampayan, P.A.; Andersen, G.L.; Sani, R.K. Microbial and Mineralogical Characterizations of Soils Collected from the Deep Biosphere of the Former Homestake Gold Mine, South Dakota. Microb. Ecol. 2010, 60, 539-550. [CrossRef] [PubMed]

9. Rastogi, G.; Osman, S.; Vaishampayan, P.A.; Stetler, L.D.; Sani, R.K. Microbial Diversity in Uranium Mining-Impacted Soils as Revealed by High-Density 16S Microarray and Clone Library. Microb. Ecol. 2010, 59, 94-108. [CrossRef] [PubMed]

10. Li, M.; Tian, H.; Wang, L. Bacterial Diversity in Linglong Gold Mine, China. Geomicrobiol. J. 2016, 34, $267-273$. [CrossRef]

11. Schippers, A.; Breuker, A.; Blazejak, A.; Bosecker, K.; Kock, D.; Wright, T.L. The biogeochemistry and microbiology of sulfidic mine waste and bioleaching dumps and heaps, and novel Fe (II)-oxidizing bacteria. Hydrometallurgy 2010, 104, 342-350. [CrossRef]

12. Yang, Y.; Yang, L.I.; Sun, Q. Archaeal and bacterial communities in acid mine drainage from metal-rich abandoned tailing ponds, Tongling, China. Trans. Nonferr. Met. Soc. China 2014, 24, 3332-3342. [CrossRef]

13. Zhou, Z.J.; Yin, H.Q.; Liu, Y.; Xie, M.; Qiu, G.Z.; Liu, X.D. Diversity of microbial community at acid mine drainages from Dachang metals-rich mine, China. Trans. Nonferr. Met. Soc. China 2010, 20, 1097-1103. [CrossRef]

14. Baker, B.J.; Moser, D.P.; MacGregor, B.J.; Fishbain, S.; Wagner, M.; Fry, N.K.; Jackson, B.; Speolstra, N.; Loos, S.; Takai, K.; et al. Related assemblages of sulphate-reducing bacteria associated with ultradeep gold mines of South Africa and deep basalt aquifers of Washington State. Environ. Microbiol. 2003, 5, 267. [CrossRef] [PubMed]

15. Sen, A.M.; Johnson, D.B. Acidophilic sulphate-reducing bacteria: Candidates for bioremediation of acid mine drainage. Process Metall. 1999, 9, 709-718. [CrossRef]

16. Hao, C.; Wang, L.; Gao, Y.; Zhang, L.; Dong, H. Microbial diversity in acid mine drainage of Xiang Mountain sulfide mine, Anhui Province, China. Extremophiles 2010, 14, 305-314. [CrossRef] [PubMed]

17. Korehi, H.; Blothe, M.; Sitnikova, M.A.; Dold, B.; Schippers, A. Metal mobilization by iron-and sulfur-oxidazing bacteria in multiple extreme mine tailings in the Atacama Desert, Chile. Environ. Sci. Technol. 2013, 47, 2189-2196. [CrossRef] [PubMed]

18. Johnson, D.B. Acidophilic microbial communities: Candidates for bioremediation of acidic mine effluents. Int. Biodeterior. Biodegrad. 1995, 35, 41-58. [CrossRef]

19. Hallberg, K.B. New perspectives in acid mine drainage microbiology. Hydrometallurgy 2010, 104, 448-453. [CrossRef] 
20. Vijayaraghavan, K.; Yun, Y.S. Bacterial biosorbents and biosorption. Biotechnol. Adv. 2008, 26, $266-291$. [CrossRef] [PubMed]

21. Shaw, D.R.; Dussan, J. Mathematical modelling of toxic metal uptake and efflux pump in metal-resistant bacterium Bacillus cereus isolated from heavy crude oil. Water Air Soil. Pollut. 2015, 226, 112-114. [CrossRef]

22. Velasquez, L.; Dussan, J. Biosorption and bioaccumulation of heavy metals on dead and living biomass of Bacillus sphaericus. J. Hazard. Mater. 2009, 167, 713-716. [CrossRef] [PubMed]

23. Das, A.P.; Ghosh, S. Bioleaching of Manganese from mining waste materials. Mater. Today Commun. 2018, 5, 2381-2390. [CrossRef]

24. Tuzen, M.; Uluozlu, O.D.; Usta, C.; Soylak, M. Biosorption of copper(II), lead(II), iron(III) and cobalt(II) on Bacillus sphaericus-loaded Diaion SP-850 resin. Anal. Chim. Acta 2007, 581, 241-246. [CrossRef] [PubMed]

25. Reith, F.; Zammit, C.M.; Rogers, S.L.; McPhail, D.C.; Brugger, J. Potential utilisation of micro-organisms in gold processing: A review. Miner. Process. Extr. Metall. Rev. 2012, 121, 251-260. [CrossRef]

26. Reith, F.; Etschmann, B.; Grosse, C.; Moors, H.; Benotmane, M.A.; Monsieurs, P.; Doonan, C.; Vogt, S.; Lai, B.; Martinez-Criado, G.; et al. Mechanisms of gold biomineralization in the bacterium Cupriavidus metallidurans. Proc. Natl. Acad. Sci. USA 2009, 106, 17757-17762. [CrossRef] [PubMed]

27. Southam, G.; Saunders, J.A. The geomicrobiology of ore deposits. Econ. Geol. 2005, 100, 1067-1084. [CrossRef]

28. Reith, F.; Lengke, M.F.; Falconer, D.; Craw, D.; Southam, G. Winogradsky review-The geomicrobiology of gold. ISME 2007, 1, 567-584. [CrossRef] [PubMed]

29. Lengke, M.F.; Ravel, B.; Fleet, M.E.; Wanger, G.; Gordon, R.A.; Southam, G. Mechanisms of gold bioaccumulations by filamentous cyanobacteria from gold(III)-chloride complex. Environ. Sci. Technol. 2006, 40, 6304-6309. [CrossRef] [PubMed]

30. Lozano, L.C.; Dussan, J. Metal tolerance and larvicidal activity of Lysinibacillus sphaericus. World J. Microbiol. Biotechnol. 2013, 29, 1383-1389. [CrossRef] [PubMed]

31. Manchola, L.; Dussan, J. Lysinibacillus sphaericus and Geobacillus sp. Biodegradation of Petroleum Hydrocarbons and Biosurfactant Production. Remediation 2014, 25, 85-100. [CrossRef]

32. Pollmann, K.; Raff, J.; Merroun, M.; Fahmy, K.; Selenska-Pobell, S. Metal binding by bacteria from uranium mining waste piles and its technological applications. Biotechnol Adv. 2006, 24, 58-68. [CrossRef] [PubMed]

33. Da Costa, A.C.A.; Pereira, F. Bioaccumulation of copper, zinc, cadmium and lead by Bacillus sp., Bacillus cereus, Bacillus sphaericus and Bacillus subtilis. Braz. J. Microbiol. 2001, 32, 1-5. [CrossRef]

34. Lapage, S.P.; Shelton, J.E.; Mitchell, T.G. Methods in Microbiology; Academic Press: Cambridge, MA, USA, 1970; p. 116.

35. Fox, J.G.; Yan, L.L.; Dewhirst, F.E.; Paster, B.J.; Shames, B.; Murphy, J.C.; Hayward, A.; Belcher, J.C.; Mendes, E.N. Helicobacter bilis sp. nov., a novel Helicobacter species isolated from bile, livers, and intestines of aged, inbred mice. J. Clin. Microbiol. 1995, 33, 445-454. [PubMed]

36. Santana-Martinez, J.C.; Silva, J.J.; Dussan, J. Efficacy of Lysinibacillus sphaericus against mixed-cultures of field-collected and laboratory larvae of Aedes aegypti and Culex quinquefasciatus. Bull. Entomol. Res. 2018, 53, 183-191. [CrossRef] [PubMed]

37. Moawed, E.A.; El-Shahat, M.F. Synthesis, characterization of low density polyhydroxy polyurethane foam and its application for separation and determination of gold in water and ores samples. Anal. Chim. Acta 2013, 788, 200-207. [CrossRef] [PubMed]

38. Castillo González, C.M. Caracterización Molecular De La Resistencia A Mercurio Mercúrico De Bacterias Nativas Colombianas; Undergraduated, Universidad de los Andes: Bogotá, Colombia, 2007.

39. Shaw, D.R.; Dussan, J. Transcriptional analysis and molecular dynamics simulations reveal the mechanism of toxic metals removal and efflux pumps in Lysinibacillus sphaericus OT4b.31. Int. Biodeterior. Biodegrad. 2017, 127, 46-61. [CrossRef]

40. Romero de Pérez, G. Método de procesamiento de los tejidos para microscopía electrónica de transmisión. In Microscopía Electrónica de Transmisión (MET) Área Biomédica: Teoría y Práctica; Academia de Ciencias Exactas, Físicas y Naturales: Madrid, Spain, 2003; pp. 264-265.

41. Cifuentes, D.P.; Ocampo, M.; Curtidor, H.; Vanegas, M.; Forero, M.; Patarroyo, M.E.; Patarroyo, M.A. Mycobacterium tuberculosis Rv0679c protein sequences involved in host-cell infection: Potential TB vaccine candidate antigen. BMC Microbiol. 2010, 10, 109. [CrossRef] [PubMed]

42. Kimura, M. A simple method for estimating evolutionary rate of base substitutions through comparative studies of nucleotide sequences. J. Mol. Evol. 1980, 16, 111-120. [CrossRef] [PubMed] 
43. Felsenstein, J. Confidence limits on phylogenies: An approach using the bootstrap. Evolution 1985, 39, 783-791. [CrossRef] [PubMed]

44. Pum, D.; Sleytr, U.B. The application of bacterial S-layers in molecular nanotechnology. Trends Biotechnol. 1999, 17, 8-12. [CrossRef]

45. Sleytr, U.B.; Györvary, E.; Pum, D. Crystallization of S-layer protein lattices on surfaces and interfaces. Prog. Org. Coat. 2003, 47, 279-287. [CrossRef]

46. Kalishwaralal, K.; Deepak, V.; Kumar, S.; Pandian, S.R.K; Gurunathan, S. Biological synthesis of gold nanocubes from Bacillus licheniformis. Bioresour. Technol. 2009, 100, 5356-5358. [CrossRef] [PubMed]

47. Wu, J.W.; Ng, I.S. Biofabrication of gold nanoparticles by Shewanella species. Bioresour. Bioprocess. 2017, 4, 1-9. [CrossRef]

48. Sá-Pereira, P.; Rodrigues, M.; Simões, F.; Domingues, L.; Videira e Castro, I. Bacterial activity in heavy metals polluted soils: Metal efflux systems in native rhizobial strains. Geomicrobiol. J. 2009, 26, 281-288. [CrossRef]

49. Nies, D.H. Efflux-mediated heavy metal resistance in prokaryotes. FEMS Microbiol. Rev. 2003, 27, 313-339. [CrossRef]

50. Gerbino, E.; Carasi, P.; Mobili, P.; Serradell, M.A.; Gómez-Zavaglia, A. Role of S-layer proteins in bacteria. World J. Microbiol. Biotechnol. 2015, 31, 1877-1887. [CrossRef] [PubMed]

51. Fahmy, K.; Merroun, M.; Pollmann, K.; Raff, J.; Savchuk, O.; Hennig, C.; Selenska-Pobell, S. Secondary structure and Pd (II) coordination in S-layer proteins from Bacillus sphaericus studied by infrared and X-ray absorption spectroscopy. Biophys. J. 2009, 91, 996-1007. [CrossRef] [PubMed]

52. Hulkoti, N.I.; Taranath, T.C. Biosynthesis of nanoparticles using microbes-A review. Colloids Surf. B 2014, 121, 474-483. [CrossRef] [PubMed]

53. Shedbalkar, U.; Singh, R.; Wadhwani, S.; Gaidhani, S.; Chopade, B.A. Microbial synthesis of gold nanoparticles: Current status and future prospects. Adv. Colloid Interface Sci. 2014, 209, 40-48. [CrossRef] [PubMed]

54. Dykman, L.A.; Khlebtsov, N.G. Gold Nanoparticles in Biology and Medicine: Recent Advances and Prospects. Acta Nat. 2011, 3, 34-55.

(C) 2018 by the authors. Licensee MDPI, Basel, Switzerland. This article is an open access article distributed under the terms and conditions of the Creative Commons Attribution (CC BY) license (http:/ / creativecommons.org/licenses/by/4.0/). 